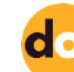

http://doi.org/10.22282/ojrs.2021.82

\title{
EXAMINATION OF DIGITAL LITERACY LEVELS OF THE SPORTS SCIENCES FACULTY STUDENTS
}

\author{
Berkan BOZDAĞ, Murat ERGIN
}

ABSTRACT
$\begin{array}{ll}\text { These days, individuals need more and } & \text { university students, } 148 \text { female and } 190 \\ \text { more skills in order to keep up with the } & \text { male, studying at Aksaray University } \\ \text { rapidly developing technology and to use } & \text { Faculty of Sport Sciences and Yozgat } \\ \text { the digital world effectively. In this regard, } & \text { Bozok University Faculty of Sport Sciences } \\ \text { information technologies emerge as an } & \text { in 2019-2020. "Personal information form" } \\ \text { important tool and it is important to provide } & \text { and "Digital Literacy Scale (DLS)" were } \\ \text { individuals with digital literacy in order to } & \text { used in order to obtain the data. As a result } \\ \text { use these tools effectively. With this study, } & \text { of the research, no statistically significant } \\ \text { it is aimed to reveal the digital literacy } & \text { difference was found in terms of students' } \\ \text { levels of the students by examining the } & \text { gender and department variables. A } \\ \text { digital literacy levels of university students } & \text { statistically significant difference was } \\ \text { studying at the faculty of sports sciences in } & \text { determined in favor of Aksaray University } \\ \text { terms of various variables. The study group } & \text { students in the sub-dimension of the } \\ \text { of the research consists of a total of } 338 & \text { "attitude and cognitive" scale. }\end{array}$

Key Words: Technologies, Digital Literacy 


\section{INTRODUCTION}

Today, the effect of digital technology is felt in every stage of human life. With the increasing importance of knowledge, the search for and production of information has increased exponentially until the century we live in (Y1lmaz, 2010) and reaching the desired information due to this rapid increase has become complex and difficult (Shenton, 2009). It is important to have acquired digital literacy skills at the point of accuracy and accessibility of information that can be kept, stored and shared by digitalization (Solmaz et al, 2017).

Although the concept of "literacy" emerged only as the skill of reading and writing symbols on paper in the process of its historical development (Önal, 2007), today, it is defined as perceiving and interpreting messages received in parallel with digital technology with critical and creative thinking skills (Thoman et al., 2008). While Gilster (1997), for the first time in the late 1990s, defined the concept of digital literacy as the ability to use and understand information provided by computers from wide sources in different ways, it appears as determining, accessing, managing, integrating and evaluating digital resources according to Martin (2005).

With the rapid developments in digital technologies changing traditional reading and writing skills (Karabacak and Sezgin, 2019), and especially today, education and training through distance education due to the Covid-19 pandemic has made digital literacy a mandatory skill for students to acquire. According to Bozkurt and Çoşkun (2018), the internet has become a part of daily life and students have started to take more places in the digital world. According to Hamutoğlu, Güngören, Uyanık, and Erdoğan (2017), digital literacy has become much more important than traditional literacy today. Digital literacy requires having the ability to reach the right information, to produce the right information, to share the information that has been reached or produced, and to use technology in education and training processes by enabling the correct use of technology. It has become important to know how we should use technology as well as for what purpose (Özerbaş and Kuralbayeva, 2018).

For this reason, discussions on digital literacy and learning-teaching have focused on the concept of digital literacy that individuals need to use technology effectively, efficiently and critically (Buckingham, 2010), and studies have been conducted on this skill. 
In the digital world that has turned into an ocean of knowledge, following the developments in sports sciences and knowing that the right information should be found and used has increased the importance of the concept of digital literacy. Considering all these situations, it is important to determine the digital literacy skills of the athletes. In this context, it is thought that this study, which was conducted in order to determine the digital literacy levels of students studying at the Faculty of Sports Sciences and to compare them with various variables, will contribute to the relevant literature.

\section{METHOD}

\section{Research Model}

Screening model was used in this research. Büyüköztürk et al. (2018) defined screening research as studies aiming to collect data to determine certain characteristics of a group. In this context, the research is a relational screening model. This model is expressed as research approaches that aim to describe a past or present situation as it exists (Karasar, 2008).

\section{Research Group}

Sample of study consists of a total of 338 university students, 148 female and 190 male, studying at Aksaray University Faculty of Sport Sciences and Yozgat Bozok University Faculty of Sport Sciences in the academic year 2019-2020. 
Table 1 shows the frequency and percentage distributions regarding the demographic characteristics of the students.

Table 1. Frequency and Percentage Distributions Regarding the Demographic Characteristics of the Students

\begin{tabular}{|c|c|c|c|}
\hline Variable & Groups & $\mathbf{n}$ & $\%$ \\
\hline \multirow{2}{*}{ Gender } & Female & 148 & 43.8 \\
\hline & Male & 190 & 56.2 \\
\hline \multirow{2}{*}{ University } & Yozgat & 195 & 57.7 \\
\hline & Aksaray & 143 & 42.3 \\
\hline \multirow{2}{*}{ Department } & PET & 156 & 46.2 \\
\hline & Coaching Education & 182 & 53.8 \\
\hline \multirow{4}{*}{ Grade } & 1st grade & 159 & 47.0 \\
\hline & 2nd grade & 84 & 24.9 \\
\hline & 3rd grade & 60 & 17.8 \\
\hline & 4 th grade & 35 & 10.4 \\
\hline \multirow{5}{*}{ Internet Usage } & $1-2$ hours & 83 & 24.6 \\
\hline & 3-4 hours & 115 & 34.0 \\
\hline & 5-6 hours & 93 & 27.5 \\
\hline & 7 hours or more & 47 & 13.9 \\
\hline & Total & 339 & 100 \\
\hline
\end{tabular}

When Table 1 is examined, it is seen that the frequency and percentage distribution is given according to the demographic characteristics of the students. Considering the distribution of students by gender, 148 (43.8\%) female students and 190 (56.2\%) male students participated in the study. Considering the distribution of students according to their universities, 195 $(57.7 \%)$ study at Yozgat Bozok University and 143 (42.3\%) at Aksaray University. When the distribution of students according to the departments they study in is examined, 156 (46.2\%) study in Physical Education and Sports Teaching and 182 (53.8\%) in Coaching (Education) departments. Examining the distribution of students by grade level, 159 (47.0\%) study at the 1st grade, $84(24.9 \%)$ at the 2nd grade, $60(17.8 \%)$ at the 3rd grade, $35(10.4 \%)$ at the 4 th grade level. Examining the distribution of daily internet usage of students in the last week, 83 (24.6\%) students use the internet between 1-2 hours, 115 (34.0\%) students between 3-4 hours, $93(27.5 \%)$ students 5-6 47 (13.9\%) students for 7 hours or more. 


\section{Data Collection Tools}

In this study, "Personal Information Form" and "Digital Literacy Scale (DLS)" developed by $\mathrm{Ng}$ (2012) and adapted into Turkish by Hamutoğlu et al. (2017) were used as data collection tools

\section{Digital Literacy Scale}

The scale consists of 4 sub-dimensions "attitude, technique, cognitive and social" and 17 items. Scoring in the scale using five-point Likert type rating is (1) strongly disagree, (5) strongly agree. There is no reverse scored item in the scale. The highest score that can be obtained from the scale is 85 , and the lowest score is 17 . Transactions can be performed on the scores obtained from the sub-dimensions of the scale, as well as on the total score obtained from the scale. The higher scores obtained from the DLS sub-dimensions and the overall scale indicate high digital literacy. The Cronbach alpha coefficient calculated for the whole scale is 93. Internal consistency coefficients for the sub-dimensions were found to be .88 for the Attitude sub-dimension, .89 for the Technique sub-dimension, .70 for the Cognitive subdimension and .72 for the Social sub-dimension. Test-retest reliability study was found to be $.98(\mathrm{n}=53)$. This is .98 for the whole scale, .89 for the Attitude sub-dimension, .90 for the Technique sub-dimension, .87 for the Cognitive sub-dimension, and .79 for the Social subdimension. For this research, the reliability of the scale was found by calculating the Cronbach Alpha Coefficient. At the end of the analysis, the reliability coefficient of the digital literacy scale in this study was found to be .93 . Considering the reliability coefficients of the subdimensions of the scale, it was calculated as .86 for the "attitude dimension", .86 for the "technique dimension", .70 for the "cognitive dimension" and .62 for the "social dimension". Scales with a reliability coefficient of .70 and above are considered to be reliable (Büyüköztürk, 2010; Özdamar 1999). It is seen that the sub-dimensions of the digital literacy scale and the reliability coefficients for the whole scale are at a sufficient level.

Table 2. Digital Literacy Scale Sub-Dimensions and Items

\begin{tabular}{ccc}
\hline Sub-dimensions & Number of Item & Items \\
\hline Attitude Dimension & 7 & $1,2,3,4,5,6,7$. \\
\hline Technique Dimension & 6 & $8,9,10,11,12,13$. \\
\hline Cognitive Dimension & 2 & 14 ve 15. \\
\hline Social Dimension & 2 & 16 ve 17. \\
\hline
\end{tabular}




\section{Data Analysis}

Data were analyzed with SPSS 22.0 package program. With the Shapiro-Wilk test, it was determined that the data showed a normal distribution ( $p>0.05)$. Group comparisons were made by (Independent Sample t Test), ANOVA test and Tukey test. Significance level was taken as $\alpha=0.05$.

\section{FINDINGS}

Table 3. Comparison of the Scores of the Participants on the Digital Literacy Scale According to Their Gender ( $\mathrm{t}$ Test)

\begin{tabular}{|c|c|c|c|c|c|c|c|}
\hline Statements & Group & $\mathbf{N}$ & Mean & Sd & $\mathbf{t}$ & df & $\mathbf{p}$ \\
\hline \multirow{2}{*}{ Attitude } & Female & 148 & 3.32 & 0.87 & \multirow{2}{*}{1.206} & \multirow{2}{*}{336} & \multirow{2}{*}{.229} \\
\hline & Male & 190 & 3.18 & 1.17 & & & \\
\hline \multirow{2}{*}{ Technique } & Female & 148 & 3.74 & 0.85 & \multirow{2}{*}{.616} & \multirow{2}{*}{336} & \multirow{2}{*}{.538} \\
\hline & Male & 190 & 3.68 & 0.99 & & & \\
\hline \multirow{2}{*}{ Cognitive } & Female & 148 & 3.45 & 0.92 & \multirow{2}{*}{.248} & \multirow{2}{*}{336} & \multirow{2}{*}{.804} \\
\hline & Male & 190 & 3.42 & 1.13 & & & \\
\hline \multirow{2}{*}{ Social } & Female & 148 & 3.23 & 1.06 & \multirow{2}{*}{-1.050} & \multirow{2}{*}{336} & \multirow{2}{*}{.295} \\
\hline & Male & 190 & 3.36 & 1.15 & & & \\
\hline
\end{tabular}

$(\mathrm{p}>0.05)$

According to Table 3, the mean scores of the students participating in the study on the digital literacy scale did not show a statistically significant difference according to the gender variable $(p>0.05)$.

Table 4. Comparison of Scores of Participants on the Digital Literacy Scale According to Their Universities ( $\mathrm{t}$ Test)

\begin{tabular}{|c|c|c|c|c|c|c|c|}
\hline Statements & Group & $\mathbf{N}$ & Mean & Sd & $\mathbf{t}$ & df & $\mathbf{p}$ \\
\hline \multirow{2}{*}{ Attitude } & Bozok & 195 & 3.12 & 1.02 & \multirow{2}{*}{-2.510} & \multirow{2}{*}{336} & \multirow{2}{*}{$.013^{*}$} \\
\hline & Aksaray & 143 & 3.41 & 1.07 & & & \\
\hline \multirow{2}{*}{ Technique } & Bozok & 195 & 3.67 & 0.89 & \multirow{2}{*}{-.782} & \multirow{2}{*}{336} & \multirow{2}{*}{.435} \\
\hline & Aksaray & 143 & 3.75 & 0.98 & & & \\
\hline \multirow{2}{*}{ Cognitive } & Bozok & 195 & 3.32 & 1.04 & \multirow{2}{*}{-2.296} & \multirow{2}{*}{336} & \multirow{2}{*}{$.022 *$} \\
\hline & Aksaray & 143 & 3.58 & 1.02 & & & \\
\hline \multirow{2}{*}{ Social } & Bozok & 195 & 3.29 & 1.11 & \multirow{2}{*}{-.281} & \multirow{2}{*}{336} & \multirow{2}{*}{.779} \\
\hline & Aksaray & 143 & 3.32 & 1.13 & & & \\
\hline
\end{tabular}

$(* \mathrm{p}<0.05)$ 
According to Table 4, the mean scores of the students participating in the study on the digital literacy scale showed a statistically significant difference in favor of Aksaray University students in the "Attitude and Cognitive" sub-dimension according to the university variable $(\mathrm{p}<0.05)$. No statistically significant difference was found between the groups in other subdimensions $(\mathrm{p}>0.05)$.

Table 5. Comparison of Scores of Participants on the Digital Literacy Scale According to Their Departments (t Test)

\begin{tabular}{|c|c|c|c|c|c|c|c|}
\hline Statements & Group & $\mathbf{n}$ & Mean & Sd & $\mathbf{t}$ & df & $\mathbf{p}$ \\
\hline \multirow{2}{*}{ Attitude } & PET & 156 & 3.22 & 1.01 & \multirow{2}{*}{-.312} & \multirow{2}{*}{336} & \multirow{2}{*}{.755} \\
\hline & Coaching Education & 182 & 3.26 & 1.09 & & & \\
\hline \multirow{2}{*}{ Technique } & PET & 156 & 3.81 & 0.90 & \multirow{2}{*}{1.920} & \multirow{2}{*}{336} & \multirow{2}{*}{.056} \\
\hline & Coaching Education & 182 & 3.62 & 0.95 & & & \\
\hline \multirow{2}{*}{ Cognitive } & PET & 156 & 3.47 & 1.06 & \multirow{2}{*}{.565} & \multirow{2}{*}{336} & \multirow{2}{*}{.572} \\
\hline & Coaching Education & 182 & 3.40 & 1.02 & & & \\
\hline \multirow{2}{*}{ Social } & PET & 156 & 3.42 & 1.12 & \multirow{2}{*}{1.761} & \multirow{2}{*}{336} & \multirow{2}{*}{.079} \\
\hline & Coaching Education & 182 & 3.20 & 1.10 & & & \\
\hline
\end{tabular}

$(\mathrm{p}>0.05)$

According to Table 5, the mean scores of the students participating in the study on the digital literacy scale did not show a statistically significant difference according to the department variable $(\mathrm{p}>0.05)$. 
Table 6. Comparison of Scores of Participants on the Digital Literacy Scale According to Their Grade Level (One-Way ANOVA)

\begin{tabular}{|c|c|c|c|c|c|c|c|}
\hline Factors & Group & $\mathbf{n}$ & Mean & Sd & $\mathbf{F}$ & $\mathbf{p}$ & Post-Hoc \\
\hline \multirow{5}{*}{ Attitude } & $1^{\text {st }}$ grade & 159 & 3.10 & 1.04 & \multirow{5}{*}{5.217} & \multirow{5}{*}{$.002 *$} & \multirow{5}{*}{$1<3 ; 1<4 ; 2<3 ; 2<4$} \\
\hline & $2^{\text {nd }}$ grade & 84 & 3.14 & 0.97 & & & \\
\hline & $3^{\text {rd }}$ grade & 60 & 3.50 & 1.09 & & & \\
\hline & $4^{\text {th }}$ grade & 35 & 3.73 & 1.02 & & & \\
\hline & Total & 338 & 3.24 & 1.05 & & & \\
\hline \multirow{5}{*}{ Technique } & $1^{\text {st }}$ grade & 159 & 3.75 & 0.94 & \multirow{5}{*}{2.396} & \multirow{5}{*}{.068} & \\
\hline & $2^{\text {nd }}$ grade & 84 & 3.48 & 0.92 & & & \\
\hline & $3^{\text {rd }}$ grade & 60 & 3.79 & 0.93 & & & \\
\hline & $4^{\text {th }}$ grade & 35 & 3.88 & 0.83 & & & \\
\hline & Total & 338 & 3.71 & 0.93 & & & \\
\hline \multirow{5}{*}{ Cognitive } & $1^{\text {st }}$ grade & 159 & 3.37 & 1.09 & \multirow{5}{*}{1.780} & \multirow{5}{*}{.151} & \\
\hline & $2^{\text {nd }}$ grade & 84 & 3.36 & 0.88 & & & \\
\hline & $3^{\text {rd }}$ grade & 60 & 3.50 & 1.11 & & & \\
\hline & $4^{\text {th }}$ grade & 35 & 3.79 & 0.99 & & & \\
\hline & Total & 338 & 3.43 & 1.04 & & & \\
\hline \multirow{5}{*}{ Social } & $1^{\text {st }}$ grade & 159 & 3.24 & 1.14 & \multirow{5}{*}{3.043} & \multirow{5}{*}{$.029 *$} & \multirow{5}{*}{$1<4 ; 2<4$} \\
\hline & $2^{\text {nd }}$ grade & 84 & 3.12 & 1.01 & & & \\
\hline & $3^{\text {rd }}$ grade & 60 & 3.48 & 1.20 & & & \\
\hline & $4^{\text {th }}$ grade & 35 & 3.71 & 0.98 & & & \\
\hline & Total & 338 & 3.30 & 1.11 & & & \\
\hline
\end{tabular}

$(* \mathrm{p}<0.05)$

According to Table 6, the scores of the students participating in the study on the digital literacy scale showed a statistically significant difference according to the grade levels ( $p$ $<0.05)$. As a result of the Tukey test conducted to determine which group or groups caused the difference determined by the ANOVA test, the "Attitude" sub-dimension scores of the students in the 1st and 2nd grade are lower than the scores of the 3rd and 4th grade students. "Social" sub-dimension scores of 4 th grade students are higher than the scores of 1 st and 2 nd grade students. No statistically significant difference was found in terms of grade level in "Technical" and "Cognitive" sub-dimensions ( $\mathrm{p}>0.05)$. 
Table 7. Comparison of Scores of Participants on the Digital Literacy Scale According to Internet Usage (One-Way ANOVA)

\begin{tabular}{|c|c|c|c|c|c|c|c|}
\hline Factors & Group & $\mathbf{n}$ & Mean & Sd & $\mathbf{F}$ & $\mathbf{p}$ & Post-Hoc \\
\hline \multirow{5}{*}{ Attitude } & (1) $1-2$ hours & 83 & 2.79 & 1.19 & \multirow{5}{*}{7.283} & \multirow{5}{*}{$.000 *$} & \multirow{5}{*}{$1<2 ; 1<3 ; 1<4$} \\
\hline & (2) 3-4 hours & 115 & 3.41 & 0.91 & & & \\
\hline & (3) 5-6 hours & 93 & 3.33 & 0.97 & & & \\
\hline & (4) 7 hours and more & 47 & 3.47 & 1.05 & & & \\
\hline & Total & 338 & 3.24 & 1.05 & & & \\
\hline \multirow{5}{*}{ Technique } & (1) 1-2 hours & 83 & 3.40 & 1.12 & \multirow{5}{*}{6.217} & \multirow{5}{*}{$.000 *$} & \multirow{5}{*}{$\begin{array}{c}1<2 ; 1<3 ; 1<4 ; \\
2<4 ; 3<4\end{array}$} \\
\hline & (2) 3-4 hours & 115 & 3.72 & 0.85 & & & \\
\hline & (3) 5-6 hours & 93 & 3.77 & 0.83 & & & \\
\hline & (4) 7 hours and more & 47 & 4.09 & 0.78 & & & \\
\hline & Total & 338 & 3.71 & 0.93 & & & \\
\hline \multirow{5}{*}{ Cognitive } & (1) 1-2 hours & 83 & 3.07 & 1.26 & \multirow{5}{*}{5.686} & \multirow{5}{*}{$.001 *$} & \multirow{5}{*}{$1<2 ; 1<3 ; 1<4$} \\
\hline & (2) 3-4 hours & 115 & 3.58 & 0.95 & & & \\
\hline & (3) 5-6 hours & 93 & 3.42 & 0.91 & & & \\
\hline & (4) 7 hours and more & 47 & 3.73 & 0.87 & & & \\
\hline & Total & 338 & 3.43 & 1.04 & & & \\
\hline \multirow{5}{*}{ Social } & (1) 1-2 hours & 83 & 2.99 & 1.20 & \multirow{5}{*}{5.608} & \multirow{5}{*}{$.001 *$} & \multirow{5}{*}{$\begin{array}{c}1<2 ; 1<3 ; 1<4 ; \\
2<4 ; 3<4\end{array}$} \\
\hline & (2) 3-4 hours & 115 & 3.36 & 1.02 & & & \\
\hline & (3) 5-6 hours & 93 & 3.35 & 1.09 & & & \\
\hline & (4) 7 hours and more & 47 & 3.80 & 1.07 & & & \\
\hline & Total & 338 & 3.30 & 1.11 & & & \\
\hline
\end{tabular}

$(* \mathrm{p}<0.05)$

According to Table 7, the scores of the students participating in the study on the digital literacy scale showed a statistically significant difference compared to internet usage $(\mathrm{p}<0.05)$. As a result of the Tukey test conducted in order to determine which group or groups caused the difference determined by the ANOVA test, "Attitude" and "Cognitive" sub-dimension scores of students, who use the internet for 1-2 hours, are lower than the scores of other students. While the "Technique" and "Social" sub-dimension scores of the students, who use the internet for 1-2 hours, are lower than the other students, the "Technique" and "Social" sub-dimension scores of the students, who use the internet for 7 hours or more, are higher than the scores of the students, who use the internet for 3-4 hours. 


\section{DISCUSSION AND CONCLUSIONS}

This research was conducted in order to determine the digital literacy levels of sports sciences faculty students and to compare them with various variables. As a result of the research, it was determined that the mean scores of the students, who participated in the study, on the digital literacy scale did not show statistically significant difference according to gender and department variables. When the literature was examined, in the study by Gürtekin (2019) on the digital literacy levels of university students, it was concluded that the digital literacy level of male students was higher than female students. Yeşildal (2018) found that men have higher digital literacy levels than women in their study on adult individuals. In the study of Özerbaş and Kuralbayeva (2018) evaluating the digital literacy levels of male candidates, it was concluded that it was significantly higher in favor of male candidates. Again, in the study conducted by Kiyıcı (2008) on teacher candidates, it was concluded that male candidates' digital literacy levels were higher than female candidates. On the other hand, in the studies of İşman and Güngören (2013), no difference was found in terms of gender. The reason why this result in the current study is different from the literature may be due to the fact that the digital literacy levels of male and female students are close to each other as a result of the digital environment of education due to the Covid-19 epidemic that emerged in December 2019.

In addition, according to the university variable, the mean scores of the students on the digital literacy scale showed a statistically significant difference in the "Attitude and Cognitive" sub-dimension in favor of Aksaray University students. This result may be due to the fact that the attitude of students studying at Aksaray University towards information and communication technologies is more positive compared to the students at Yozgat Bozok University.

The scores of the students participating in the study on the digital literacy scale showed a statistically significant difference according to the grade levels. The "Attitude" sub-dimension scores of the 1st and 2nd grade students were determined to be lower than the scores of the 3rd and 4th grade students. "Social" sub-dimension scores of 4th grade students are higher than the scores of 1st and 2nd grade students. It was determined that there was no significant difference between the "technical" and "cognitive" sub-dimensions and the grade variable. When the literature is examined, in the study conducted by Özerbaş and Kuralbayeva (2018) on teacher 
candidates, it was concluded that there was no significant difference in the digital literacy levels of teacher candidates according to grade levels in all other dimensions of the scale except for the contextual use of the scale. In the study of Gürtekin (2019) conducted on university students, it was determined that digital literacy levels do not vary according to grade levels. Again, in the studies of İşman and Güngören (2013) and Bardakc1, Akyüz, Samsa-Yetik, and Keser (2014), there was no difference in terms of grade level. In the study of Sakall1 (2015) on classroom teachers, it was concluded that the levels of classroom teacher candidates studying in the 4th grade were higher in the "Digital literate" sub-factor than those of the 1st and 2nd grade classroom teachers.

When the final finding of the study was examined, the scores of the students on the digital literacy scale showed a statistically significant difference according to internet usage. Accordingly, it was determined that students who used the internet for 1-2 hours had lower scores on the "Attitude, Cognitive, Technique and Social" dimension than other students while it was concluded that the "Technique" and "Social" dimension scores of the students who use internet for 7 hours or more are higher than the scores of the students who use internet for 3-4 hours. It can be concluded that students who use the internet for 1-2 hours have lower digital literacy knowledge than other students.

As a result, there are many variables that can affect digital literacy. These variables vary according to need. The current study is considered to be one of the pioneers of the research on the concept of digital literacy among the students of the faculty of sports sciences and in this respect, it is important for university students, who will be the adults of our future, to be supported with technological tools related to their education and to benefit from the opportunities provided by their technologies at the highest level. It is thought that it will be important to repeat the study on a larger sample in order to increase the courses and seminars related to the concept of digital literacy and to reach generalizable results.

\section{REFERENCES}

Bardakcı, S., Akyüz, H.G., Samsa-Yetik, S. ve Keser, H. (2014). Öğretmen adaylarının dijital vatandaşllk eğilimleri üzerine sosyokültürel bir inceleme. 8th International Computer \& Instructional Technologies Symposium (ICITS). Trakya University: Edirne.

Bozkurt, F. ve Çoşkun, D. (2018). 21. yy okuryazarlı̆̆ı Öğretmen adaylarının medya algılarına 
genel bir bakış. Erciyes Iletişim Dergisi, 5(4), 493-511. https://doi.org/10.17680/erciyesiletisim.381046

Buckingham, D. (2010) Defining Digital Literacy. Bachmair, B. (Ed.), Medienbildung in neuen kulturräumen (s. 59-71) içinde. VS Verlag für Sozialwissenschaften.

Büyüköztürk, Ş. (2010). Sosyal bilimler için veri analizi el kitabı. Pegem Akademi Yayınları.

Büyüköztürk, Ş., Çakmak, E. K., Akgün, Ö. E., Karadeniz, Ş. ve Demirel, F. (2017). Bilimsel araştırma yöntemleri. Pegem Atıf İndeksi,

Gilster, P. (1997). Digital literacy. Wiley Computer Pub.

Gürtekin, A. (2019). Üniversite öğrencilerinin boş zaman tutumlarl ile sosyalleşme taktikleri ve dijital okuryazarlık düzeylerinin incelenmesi, Yüksek Lisans Tezi, Ağrı İbrahim Çeçen Üniversitesi, Sosyal Bilimler Enstitüsü, Ağrı.

Hamutoğlu, N. B., Güngören, Ö. C., Uyanık, G. K. ve Erdoğan, D. G. (2017). Dijital okuryazarlık ölçeği: Türkçeye uyarlama çalışması. Ege Eğitim Dergisi, 18(1), 408-429. https://doi.org/10.12984/egeefd.329432

İşman, A. ve Güngören, O. C. (2013). Being digital citizen. Procedia-Social and Behavioral Sciences, 106, 551-556.

Karabacak, Z. İ. ve Sezgin, A. A. (2019). Türkiye'de dijital dönüşüm ve dijital okuryazarlık. Türk İdare Dergisi, 91(488), 319-343.

Karasar, N. (2008). Bilimsel araştırma yöntemi. Nobel Yayın Dağıtım.

Kıyıcı, M. (2008). Öğretmen adaylarının sayısal okuryazarlık düzeylerinin belirlenmesi, (Yayınlanmamış Doktora Tezi). Anadolu Üniversitesi Eğitim Bilimleri Enstitüsü, Eskişehir.

Martin, A. (2005). Digeulit - A European framework for digital literacy: A progress report. Journal of e-Literacy 2(2), 130-136.

Ng, W. (2012). Can we teach digital natives digital literacy?. Computers \& Education, 59(3), 1065-1078.

Önal, H. İ. (2007). Medya okuryazarlığı: Kütüphanelerde yeni çalışma alanı. Türk Kütüphaneciliği, 21(3), 335-359.

Özdamar, K. (1999). Paket programlar ile istatistiksel veri analizi 1. Kaan Kitabevi.

Özerbaş, M. A. ve Kuralbayeva, A. (2018). Türkiye ve Kazakistan öğretmen adaylarının dijital okuryazarlık düzeylerinin incelenmesi. MSKU Eğitim Fakültesi Dergisi, 5(1), 16-25. 
Sakallı, H. (2015). Sinıf ögretmeni adaylarının dijital vatandaşlı düzeyleri ile siber zorbalık eğilimleri arasindaki ilişkinin incelenmesi, Yüksek Lisans Tezi, Adnan Menderes Üniversitesi, Sosyal Bilimler Enstitüsü, Aydın.

Shenton, A. K. (2009). Information literacy and scholarly investigation: a British perspective. IFLA journal, 35(3), 226-231.

Solmaz, T., Çimen, Ü. ve Yüksel, H. (2017). Dijital çağda medya okuryazarlığının önemi. Tarih Okulu Dergisi, 10(32), 955-97.

Thoman, E., Jolls, T., Share, J., Elma, C. ve Kesten, A. (2008). 21. yüzyll okuryazarllğı: Medya okuryazarlı̆̆ına genel bir bakış ve sinıf içi etkinlikler. Ekinoks Yayınevi.

Yeşildal, M. (2018). Yetişkin bireylerde dijital okuryazarlık ve sağlık okuryazarlığı arasindaki ilişski: Konya örneği, (Yüksek Lisans tezi), Necmettin Erbakan Üniversitesi Sağlık Bilimleri Enstitüsü, Konya.

Yllmaz, H. (2010). An examination of preservice teachers' perceptions about cyberbullying. Eurasia Journal of Mathematics, Science \& Technology Education, 6(4), 263-270. 